\title{
THE EFFECTS OF WORKING CAPITAL MANAGEMENT ON THE PROFITABILITY OF NIGERIAN MANUFACTURING FIRMS
}

\author{
Omo Aregbeyen \\ Department of Economics, University of Ibadan, Ibadan, Nigeria \\ E-mail: omoareg@hotmail.com
}

Received 13 August 2011; accepted 14 December 2011

\begin{abstract}
The efficiency of working capital management (WCM) has implications for firms'profitability. This paper empirically investigates the effects of WCM on the profitability of a sample of 48 large manufacturing firms quoted on the Nigerian Stock Exchange (NSE) for the period 1993 to 2005. It is aimed at filling the gaps in a previous study and contribute to expanding and enriching the literature particularly on Nigeria and at large. The analysis examined the responses of the firms' profitability to WCM and a number of augmenting factors. Profitability was alternatively measured by gross operating profit (GOI), net operating income (NOI) and return on assets (ROA). Likewise, WCM was measured by the average collection period (ACP), average pay period (APP), inventory turnover days (ITID) and comprehensively by the cash conversion cycle (CCC). The results indicate that the firms' have been inefficient with WCM and caused significant reductions in profitability. The paper concludes that improving the efficiency of WCM is essential and recommends that manufacturing firms in Nigeria should shorten the ACP, APP, ITID and reduce their CCCs.
\end{abstract}

Keywords: manufacturing firms, WCM, CCC, efficiency, profitability, Nigeria.

Reference to this paper should be made as follows: Aregbeyen, O. 2013. The effects of working capital management on the profitability of Nigerian manufacturing firms, Journal of Business Economics and Management 14(3): 520-534.

JEL Classification: D22, L25, L60, M21.

\section{Introduction}

A significant (and positive) development in corporate financial management over the recent years has been an increased emphasis on WCM decisions. According to Appuhami (2008) WCM is a very important component of corporate finance for two main reasons. The first is that a typical firm's current assets account for a substantial proportion of total assets. The second being that the maintenance of adequate levels of current assets is required to optimize returns on investment. Indeed, firms with inadequate levels of current assets may incur shortages and have difficulties in smoothly maintaining dayto-day operations (Van Horne and Wachowicz 2000, 2004). However, funds tied up in working capital (WC) are hidden reserves that can be used to fund growth strategies, 
such as capital expansion. Firms that have earned profits and grown have underscored efficient WCM in reacting quickly and appropriately to unanticipated changes in market variables and gain competitive advantages over rivals.

Consequently, there have been several studies on the effects of WCM on the profitability of firms across countries. This study also examined the relationship between efficiency of WCM and profitability of manufacturing firms in Nigeria. The motivation is that a previous study by Falope and Ajilore (2009) bears a number of significant weaknesses. First, the sample lumped together purely manufacturing firms and service rendering firms (e.g. hospitals, aviation firms, trading companies) without taking due cognizance of the fact that WCM requirements and practices differ across broad categories of firms. The second is the single use of ROA as measure profitability. The literature identified alternative measures Exploring these alternatives, I believe would provide more insightful results. The last but fundamental is that while the study reportedly covered the period 1996-2005 for 50 firms, the reported results was for 694 firm year observations instead of 500 for which the sample and year of study suggest. This makes the reported results very questionable and doubtful.

This study has attempted to fix these weaknesses by focusing only on manufacturing firms and explored alternative measures of profitability. The study therefore, aims to expand and contribute new findings to the existing literature particularly on Nigeria and at large.

The rest of the paper is organized as follows. Section two reviews the literature on the imperatives of efficient WCM and the empirical evidences on WCM and firm profitability. The study sample and data collection as well as the method of analysis are indicated in section three. Section four presents and discusses the results obtained, while section five gives the summary and conclusion of the study.

\section{Literature review}

\subsection{Theoretical insights}

Smith (1973) noted that the failure of a large number of firms can be attributed to inefficient WCM due to the inability of financial managers to properly plan and control WC. WC is commonly understood as the fund needed to meet the day-to-day expenses of an enterprise. Technically, it is defined as the difference between a firm's current assets and liabilities (Guthman and Dougall 1948; Park and Gladson, 1963; Bhattacharya 2009). In Deloof (2003), Planware (2010) and Lukkari (2011), the major measures of WC indicated include: number of days inventories are turnover, account receivable and payable; current ratio (CR); quick ratio; WC ratio; net liquidity balance; WC requirement; and the CCC, first introduced by Gitman (1974) and later refined by Gitman and Sachdeva (1984).

The CCC captures the time lag between the expenditure for the purchase of raw materials and the collection from the sale of finished goods (Shin and Soenen 1998). Longer cash cycle means more investment in WC while shorter cycle implies otherwise. Re- 
ducing the CCC to a reasonable minimum generally leads to improved profitability, but in some cases longer cash cycle might increase profitability because it leads to higher sales (Deloof 2003).

The effective and/or efficient management of WC is therefore necessary to achieve both the long and short term goals of firms. WCM has been severally defined. For instance, Eljelly (2004) says efficient WCM involves planning and controlling current assets and liabilities in a manner that eliminates the risk of inability to meet due short term obligations on one hand and avoids excessive investment in these assets on the other. Very succinctly, KPMG (2005) sees WCM as comprising all efforts directed towards optimizing the time span during which WC is tied up in the company. The WC that a firm would need is affected by a number of factors, both internal and external (Ali and Khan 2011). Several researchers (see for example Hawawini et al.1986; Chiou and Cheng 2006; Michalski 2007; Nazir and Afza 2008, 2009) identified nature and size, manufacturing cycle, business fluctuations, production policy, turnover of circulating capital, operating efficiency, price level changes, growth and expansion activities, and credit terms/policy, among others.

\subsection{Previous studies}

The survey of previous studies was done to cover studies on several countries. However, the rendition is ordered by the year.

Deloof (2003) studied a sample of 1009 large Belgian firms from 1992-1996. WCM was measured by the CCC, while profitability was measured by NOI and GOI. The analysis combined the Pearson's correlation and regression analyses. The results indicate that WCM is not efficient and thereby negatively affect profitability. In addition, less profitable firms wait longer to pay their bills.

Seyaduzznmen (2006) reported that the efficiency of WCM of the British American Tobacco Bangladesh Company Ltd was positively related to profitability. The study was conducted for two periods of 1999-2000 and 2002-2003. Similarly, Lazaridis and Tryfonidis (2006) investigated the profitability effect of WCM in a sample of 131 companies listed in the Athens Stock Exchange for the period of 2001-2004. The results showed significant relationship between profitability, measured by GOI and the CCC. They concluded that managers can create profits by handling correctly the CCC and keeping each different component to an optimum level.

Padachi (2006) also examined the trends in WCM and its impact on performance for a sample of 58 Mauritian small manufacturing firms, using panel analysis for the period 1998-2003. ROA was used to measure profitability and the CCC for WCM. The results showed that high investment in inventories and receivables is associated with lower profitability.

Raheman and Nasr (2007) studied 94 Pakistani firms during 1999-2004. WCM was measured alternatively by ACP, APP, ITID, CCC and CR. Profitability was measured by NOI. Pearson's correlation and regression analyses were utilized. Strong negative relationship between WCM and profitability was reported. The study recommended WCM be improved. 
Garcia-Teruel and Martinez-Solano (2007) examined a panel of 8,872 Spanish SMEs during the period 1996-2002. WCM was also measured by the CCC and profitability by ROA. Univariate and multivariate analyses were conducted. A significant negative relation between profitability and ACP and ITID exist. However, there was no confirmation that APP affects ROA, as this relation losses significance when possible endogeneity problem were controlled for. Nevertheless, it was concluded that improved/efficient WCM would improve the firms' profitability.

Mathuva (2009) considered 30 firms listed on the Nairobi Stock Exchange for the periods 1993 to 2008. He used Pearson and Spearman's correlations, the pooled ordinary least square, and the fixed effects regression models to conduct data analysis. $\mathrm{He}$ found highly significant (i) negative relationship between the ACP and profitability, and (ii) positive relationship between ITID,APP and profitability.

Dănulețiu (2010) analyzed the efficiency of WCM of companies from Alba County over the period 2004-2008. The Pearson correlation analysis was utilized. Weak negative linear correlation between WCM and profitability was reported.

Gill et al.(2010) studied 88 American firms for a period of 3 years from 2005 to 2007. Significant relationship between the CCC and profitability was reported. They concluded that managers can create profits for their companies by handling correctly the CCC and by keeping accounts receivables at an optimal level.

For Turkey, Karaduman et al. (2010) investigated selected companies in the Istanbul Stock Exchange for the period of 2005-2008. The panel data methods were employed. Profitability of the firms was measured by ROA while WCM was alternatively measured by CCC, ACP, APP and ITID. All the measures bear significant negative relationship with profitability, indicating WCM was not efficient. The need for the companies to improve on WCM in order to increase profitability was emphasized.

Charitou et al. (2010) studied firms listed on the Cyprus Stock Exchange for the period 1998-2007. They hypothesized that WCM leads to improved profitability. Using multivariate regression analysis, the reported results supported the hypothesis. Specifically, the results indicate that the CCC and all its major components are associated with profitability.

Most recently, Sharma and Kumar (2011) for India examined 263 non-financial Bombay Stock Exchange listed firms from 2000 to 2008. Panel regression analysis was conducted. The findings revealed that WCM and profitability are positively correlated. Furthermore, ITID and APP are negatively correlated with profitability, whereas ACP and the CCC exhibit positive relationships.

\subsection{Summary of the literature}

The efficiency of WCM has implications for profitability. The main goal of WCM is to maintain a level of cash inflows and outflows that would create balance between each element of $\mathrm{WC}$, without which it is impossible to move or make firms function in a proper way. In addition, reliable and incessant monitoring of components of WC is required to achieve such balance. $\mathrm{CCC}$ is the popular and most comprehensive measure 
of WCM. The optimal level of CCC vis-à-vis profitability differs from firm to firm. The empirical literature indicates that firms that are efficient with WCM recorded increased profitability and vice versa. Therefore, improvement in WCM increases profitability.

\section{Methodology}

\subsection{The study sample and data collection}

The study population included manufacturing firms that have been listed since 1997 and remained in existence up till 2005. The time frame covered a thirteen year period from 1993 to 2005 . Using 1997 as the basis for drawing our sample is informed by the fact that all firms listed on the NSE will have available financial records dated back at the limit to 1993. A total of 114 firms fit into this frame. However, only 48 for which we obtained complete data set constituted the study sample.

Data were sourced from the individual firm's various issues of Annual Report and Statement of Accounts. The literature indicated various measures of profitability. This study used three measures namely NOI, GOI and ROA with each serving as check on the other. The CCC as a comprehensive measure of WCM was also used.

\subsection{Method of analysis}

Most previous studies combined descriptive/statistical and econometrics analyses. This study followed this lead by employing both approaches. The former was used to characterize the profitability and WCM patterns of the firms as well as the relationship between the two. The latter provided estimates of the association between the firms' profitability and WCM by specifying a model and applying an appropriate estimation technique. The general form of our model following in the footsteps of Deloof (2003), Raheman and Nasr (2007) and Samiloglu and Demigunes (2008) and others is as follows:

$$
\mathrm{PRT}_{\mathrm{it}}=\mathrm{a}_{0}+\sum \beta_{\mathrm{i}} \mathrm{X}_{\mathrm{it}}+\sum \mathrm{l}_{\mathrm{i}} \mathrm{Z}_{\mathrm{it}}+\mathrm{U}_{\mathrm{it}},
$$

where $\mathrm{PRT}_{\text {it }}=$ profitability of firm $\mathrm{i}$ at time $\mathrm{t} ; \mathrm{i}=1,2, \ldots \ldots .48$ firms

$\mathrm{a}_{0}=$ the intercept of equation

$\beta_{\mathrm{i}}=$ coefficients of $\mathrm{X}_{\mathrm{it}}$ variables.

$1_{\mathrm{i}} \quad=$ coefficient of $Z_{\text {it }}$ variables.

$\mathrm{X}_{\mathrm{it}}=$ the different independent variables for $\mathrm{WCM}$ of firm $\mathrm{i}$ at time $\mathrm{t}$

$\mathrm{Z}_{\mathrm{it}}=$ the different independent variables serving as control variables of firm $i$ at time $t$

$\mathrm{t}=$ time: $1,2 \ldots \ldots \ldots \ldots \ldots 13$ years

$\mathrm{Ut}=$ The error term

I then converted the above general least squares model into specified variables model as:

$$
\begin{aligned}
& \text { PRT }_{\text {it }}=a_{0+}\left(a_{1} A_{C P}+a_{2} A_{\text {APP }}+a_{3} \text { ITID }_{\text {it }}+a_{4} C_{\text {CCC }}\right)+a_{5}\left(C_{\text {it }}+\right. \\
& \left.a_{6} \text { LEV }_{\text {it }}+a_{7} \text { SIZE }_{\text {it }}+a_{8} \operatorname{GRT}_{\text {it }}+a_{9} \text { FATA }_{\text {it }}\right)+U_{\text {it }}
\end{aligned}
$$

where:

PRT : Profitability measured by NOI (Total Sales minus Cost of goods sold, including depreciation and amortization /Total Asset-Financial Asset), GOI (Operating Income 
plus depreciation/Total Assets minus Financial Assets) and ROA (Net Income/Total Asset).

ACP : Average Collection Period (= Account receivables $\times 365 /$ sales)

APP : Average Payment Period (= Accounts payable $\times 365 /$ purchases)

ITID : Inventory Turnover in Days (= Inventory $\times 365 /$ cost of sales)

CCC : Cash Conversion Cycle (= ACP plus ITID minus APP)

CR : Current Ratio - current liabilies/current assets

LEV : Total Debt/ Total Assets

SIZE : Natural Logarithm of Total Asset

GRT : Percent Changes in Sales

FATA : Financial Assets/Total Assets

\subsection{A prior expectations on the model}

In this section, I discuss the likely direction of relationship between profitability and WCM variables and others in our model. Given the focus of the study, we begin with the WCM variables.

Starting with account receivable, a negative relationship is plausible when customers take more time to assess the quality of products they buy from firms, particularly, those with declining profitability. So it is presumed that higher profits should lead to more accounts receivable, because firms with higher profits have more cash to lend to customers. The study of Deloof and Jergers (1996) provided empirical validation that firms with shortage of cash reduce investment in accounts receivable.

For account payable, delaying payments to suppliers and other creditors allows firms to assess the quality of bought products and can be an inexpensive and flexible source of financing. In this instance, it can enhance the prospect of firms' profitability. However, late payment of invoices can be costly if a discount for early payment is offered. Loosing such discounts makes firms less profitable. Less profitable firms in turn wait longer to pay their bills.

Large inventory and a generous trade credit may lead to higher sales and reduce the risk of a stock-out. Trade credit may stimulate sales because it allows customers to assess product quality before paying (Long et al. 1993; Deloof and Jegers 1996; Deloof 2003; Raheman and Nasr 2007). The flip side is that money is locked up in WC with implications for profitability (Deloof 2003). A negative relationship would ensure with declining sales, leading to lower profits and more inventory.

A longer CCC might increase profitability because it leads to higher sales. However, profitability might also decrease with the CCC, if the costs of higher investment in WC rise faster than the benefits of holding more inventories and/or granting more trade credit to customers. Therefore, to have desired positive impact on profitability, the optimal CCC must be attained. With optimal CCC, a firm would be efficient, and this will lead to increasing its profitability.

CR is expected to be negatively signed with profitability. This is because the two objectives of liquidity and profitability have inverse relationships. So, firms need to maintain 
a balance or trade-off between the two. When a balance is achieved, CR would be positively related to profitability on the presumption that debt facilities offer opportunity to actualize investment opportunities and expansion activities that they may not otherwise be able to accomplish with own funds. With a trade-off, CR and profitability would be negatively related because debt must be repaid and at a cost. With high a level of debt and servicing cost, there could be a negative relation.

On size and profitability, there are three contending postulations. The first is the traditional theory which suggests a negative relationship and premised on the assumption that large or big firms supposedly operate close to the optimum level and so would grow very little and might even have to shrink. But small firms are far below the optimum size and would need to grow faster. The second is the Gilbrat's (1931) "Law of Proportionate Effect". which states that both big and small firms have equal chance of growing at a given rate during any period of time. The third is the "bigger the better" theory that postulates that large firms have an advantage over the smaller ones because larger firms can enter into all the product lines that the smaller firms enter, while the reserve is not true owing to the presence of size and scale advantages. In addition, big firms generally have easier access to capital and money markets than less well-known small firms (Biggs et al.1996).

\section{Data analysis and discussion of results}

The data collected were analyzed descriptively and quantitatively. The results are discussed in this section.

\subsection{Descriptive analysis}

The descriptive analysis shows the average and standard deviation of the different variables as well as the minimum and maximum values. Table1 presents descriptive statistics for 48 listed Manufacturing firms for thirteen years from 1993 to 2005 and for a total of 624 firms' year observations. GOI is on average $38.7 \%$ of total asset-financial asset with a median of $34.5 \%$. Mean and median NOI and ROA are $34.7 \%$ and $18.9 \%$; and $5.5 \%$ and $5.6 \%$, respectively. The average CCC is 27.3 days with a median of -10.3 days. Firms receive payment on sales after an average of 71.4 days (the median is 60.8 days). It takes on average 191.5 days to sell inventory (median is 163.9 days) and firms wait on average 271.3 days to pay for purchases (the median is 233.1 days).

Mean GRT is $24.0 \%$ and a median of $15.3 \%$. On average, just about $6.8 \%$ of all assets are financed with financial debt with a median value of $6.4 \%$. Similarly, the mean and median FATA are $6.6 \%$ and $6.7 \%$, respectively. This suggests that most of the firms have large proportion of total assets as fixed assets. Maximum LEV stood at 5.691 with an average value of 0.676 . Size variation showed a wide margin from a minimum value of about 10 to a maximum of 21 , with mean and median values of 15 and 14 , respectively. 
Table 1. Descriptive statistics - 48 listed Nigerian manufacturing firms (1993-2005)

\begin{tabular}{lccccc}
\hline & Minimum & Maximum & Mean & Median & Std. Dev. \\
\hline ACP & 0.66 & 321.24 & 71.36 & 60.84 & 52.00 \\
\hline APP & 0.15 & 963.16 & 271.30 & 233.12 & 159.04 \\
\hline CCC & -103.89 & 805.89 & 27.40 & -10.30 & 106.79 \\
\hline CR & 0.02 & 13.87 & 1.40 & 1.24 & 0.90 \\
\hline FATA & 0.04 & 4.30 & 0.66 & 0.67 & 0.24 \\
\hline GOI & -0.65 & 7.68 & 0.39 & 0.35 & 0.44 \\
\hline GRT & -73.44 & 924.33 & 24.01 & 15.31 & 55.20 \\
\hline ITID & 3.91 & 969.47 & 191.50 & 163.90 & 135.60 \\
\hline LEV & 0.00 & 5.69 & 0.68 & 0.64 & 0.48 \\
\hline NOI & -7.75 & 8.42 & 0.35 & 0.19 & 0.97 \\
\hline ROA & -2.79 & 0.52 & 0.06 & 0.06 & 0.16 \\
\hline SIZE & 10.07 & 21.05 & 14.65 & 14.49 & 2.01 \\
\hline
\end{tabular}

\subsection{Empirical analysis}

The empirical analysis is bifurcated. The first is the correlation analysis, while the second is the regression analysis

\subsubsection{Correlation analysis}

Table 2 presents Pearson correlation coefficients for all variables. There is a negative and significant relation between the profitability and WCM measures. In specific terms, the coefficients between ACP the three measures of profitability are negative: GOI -0.12 , NOI -0.07 and ROA -0.21 . These indicate that longer ACP has negative impacts on profitability. The results for APP also bear negative and significant correlation with the profitability measures suggesting that the less profitable firms are, the longer they take to pay bills. Similarly, the coefficients between ITID and PRT are also negatively signed implying that it took longer time on the average in selling inventory or stocks, which adversely affect profitability. The CCC also bear negative coefficients with the three profitability measures, though with weaker statistical strength: -0.02 for (GOI), -0.05 for (NOI) and -0.06 for ROA. These results are indicative that the CCC has not been optimal and efficient, and impacted profitability positively as desired.

$\mathrm{CR}$ is divergently correlated with the profitability measures. While it is negatively correlated with GOI, it is positive with both NOI and ROA. FATA is positively correlated with all the three measures of profitability. This shows that FATA was sufficient enough to enable the firms seize profitable investment opportunities, and thereby facilitated profitability. GRT as expected bears positive correlations with all measures of profitability. The coefficients obtained are 0.07 for GOI, 0.17 for NOI and ROA and suggest that GRT increased profitability. LEV is both positively and negatively correlated with profitability. For GOI, it is positive with a coefficient value of 0.28 . It is negative with 


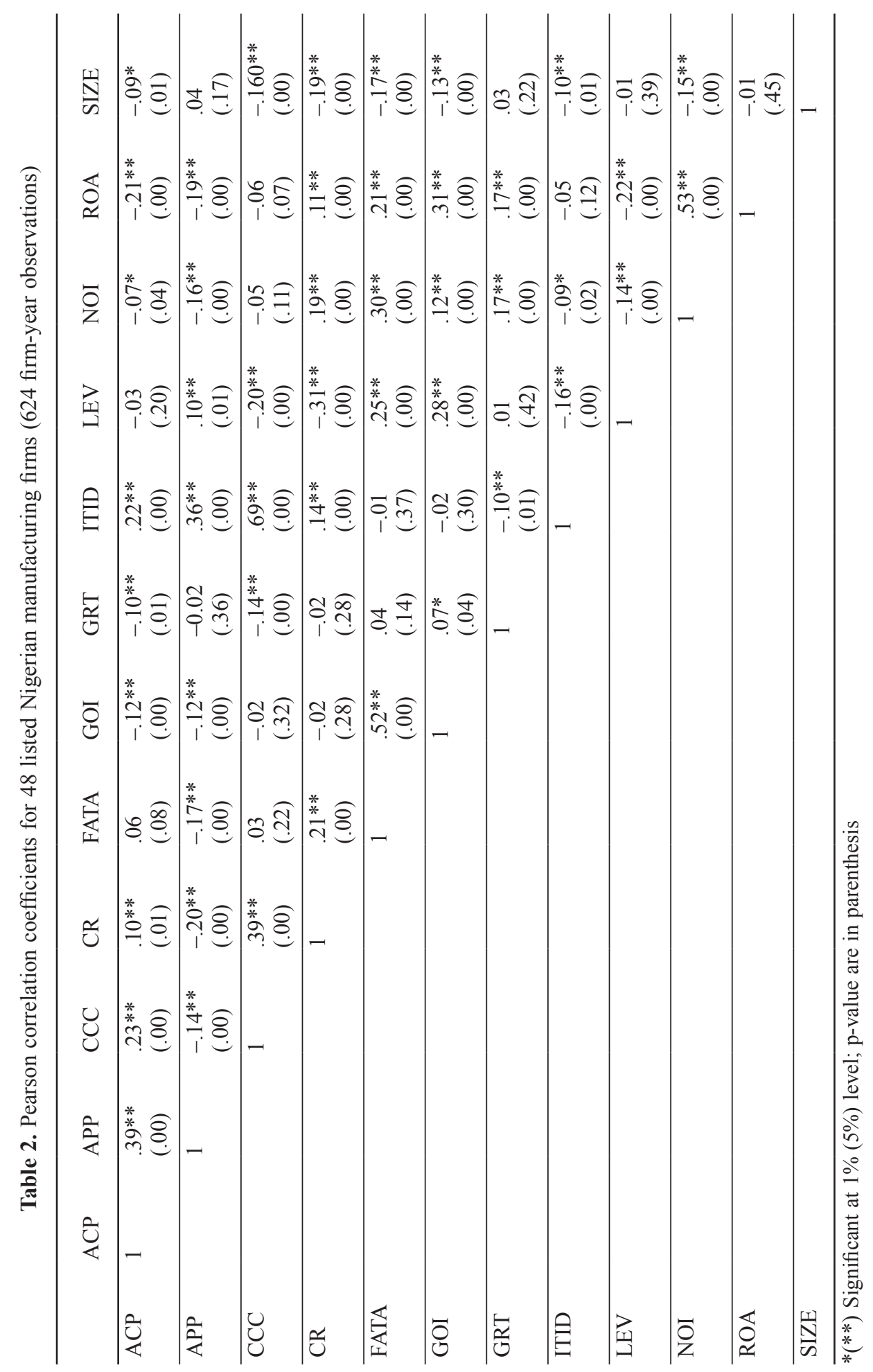


respect to NOI and ROA with coefficient values of -0.14 and -0.22 , respectively. All the coefficients are significant. The positive correlation with GOI is indicative that debt enabled the firms to actualized some of their investment plans and expansion activities, while the negative relation to NOI and ROA suggest that the cost of servicing the debt vis-à-vis the return on the investment, had reducing effect on profitability.

Lastly, size is negatively correlated with profitability. The relationship is significant in respect of GOI and NOI. These results point to the validation of the traditional theory which suggests a negative relation between size and firms performance.

\subsubsection{Regression analysis}

The regression analysis was explored with two estimation techniques/approaches. The first is the pooled regression, while the second is the fixed effect regression with crosssection weights. The cross-section weights were explored to fix the heteroskedasticity issues/problems in the data/estimation. The fixed effects regression was considered because of the simple reason that all the variables of the model are endogenous in nature. The results obtained from both, and for each variant of the model are presented in Tables $3 \mathrm{a}, 3 \mathrm{~b}$ and $3 \mathrm{c}$, respectively.

Table 3a. Regression of gross operating profit on working capital variables

\begin{tabular}{|c|c|c|c|c|c|c|c|c|}
\hline \multirow{2}{*}{$\begin{array}{l}\text { Regressions/ } \\
\text { Variable }\end{array}$} & \multicolumn{4}{|c|}{ Pooled Regression } & \multicolumn{4}{|c|}{$\begin{array}{l}\text { Fixed Effect Regression } \\
\text { (with cross-section weights) }\end{array}$} \\
\hline & 1 & 2 & 3 & 4 & 1 & 2 & 3 & 4 \\
\hline$\overline{\mathrm{C}}$ & $\begin{array}{l}0.08 \\
(0.63)\end{array}$ & $\begin{array}{l}0.04 \\
(0.32)\end{array}$ & $\begin{array}{l}-0.03 \\
(-0.25)\end{array}$ & $\begin{array}{l}-0.04 \\
(-0.32)\end{array}$ & $\begin{array}{l}0.53 \\
(4.71)^{*}\end{array}$ & $\begin{array}{l}0.67 \\
(6.19)^{*}\end{array}$ & $\begin{array}{l}0.54 \\
(4.60)^{*}\end{array}$ & $\begin{array}{l}0.63 \\
(5.48)^{*}\end{array}$ \\
\hline$\overline{\mathrm{ACP}}$ & $\begin{array}{l}-0.001 \\
(-4.24)^{*}\end{array}$ & - & - & - & $\begin{array}{l}-0.001 \\
(-6.65)^{*}\end{array}$ & - & - & - \\
\hline$\overline{\mathrm{APP}}$ & - & $\begin{array}{l}-0.0002 \\
(-1.87)^{* *}\end{array}$ & - & - & - & $\begin{array}{l}-0.0004 \\
(-8.50)^{*}\end{array}$ & - & - \\
\hline$\overline{\mathrm{CCC}}$ & - & - & $\begin{array}{l}0.0001 \\
(0.85)\end{array}$ & - & - & - & $\begin{array}{l}-0.00001 \\
(-2.02)^{*}\end{array}$ & - \\
\hline ITID & - & - & - & $\begin{array}{l}0.0001 \\
(0.56)\end{array}$ & - & - & - & $\begin{array}{l}-0.0002 \\
(-3.85)^{*}\end{array}$ \\
\hline$\overline{\mathrm{CR}}$ & $\begin{array}{l}-0.04 \\
(-2.42)^{*}\end{array}$ & $\begin{array}{l}-0.05 \\
(-2.88)^{*}\end{array}$ & $\begin{array}{l}-0.06 \\
(-2.78)^{*}\end{array}$ & $\begin{array}{l}-0.05 \\
(-2.69)^{*}\end{array}$ & $\begin{array}{l}-0.01 \\
(-1.25)\end{array}$ & $\begin{array}{l}-0.03 \\
(-2.82)^{*}\end{array}$ & $\begin{array}{l}-0.02 \\
(-1.38)\end{array}$ & $\begin{array}{l}-0.01 \\
(-1.25)\end{array}$ \\
\hline$\overline{\text { FATA }}$ & $\begin{array}{l}0.92 \\
(13.92)^{*}\end{array}$ & $\begin{array}{l}0.89 \\
(13.15)^{*}\end{array}$ & $\begin{array}{l}0.91 \\
(13.60)^{*}\end{array}$ & $\begin{array}{l}0.91 \\
(13.58)^{*}\end{array}$ & $\begin{array}{l}0.47 \\
(10.85)^{*}\end{array}$ & $\begin{array}{l}0.47 \\
(10.93)^{*}\end{array}$ & $\begin{array}{l}0.45 \\
(9.98)^{*}\end{array}$ & $\begin{array}{l}0.46 \\
(9.99)^{*}\end{array}$ \\
\hline$\overline{\text { GRT }}$ & $\begin{array}{l}0.0003 \\
(0.96)\end{array}$ & $\begin{array}{l}0.0004 \\
(1.36)\end{array}$ & $\begin{array}{l}0.0004 \\
(1.48)\end{array}$ & $\begin{array}{l}0.0004 \\
(1.43)\end{array}$ & $\begin{array}{l}0.0003 \\
(3.74)^{*}\end{array}$ & $\begin{array}{l}0.0004 \\
(4.78)^{*}\end{array}$ & $\begin{array}{l}0.001 \\
(4.58)^{*}\end{array}$ & $\begin{array}{l}0.001 \\
(4.41)^{*}\end{array}$ \\
\hline$\overline{\mathrm{LEV}}$ & $\begin{array}{l}0.11 \\
(3.27)^{*}\end{array}$ & $\begin{array}{l}0.12 \\
(3.48)^{*}\end{array}$ & $\begin{array}{l}0.12 \\
(3.38)^{*}\end{array}$ & $\begin{array}{l}0.12 \\
(3.36)^{*}\end{array}$ & $\begin{array}{l}0.02 \\
(1.07)\end{array}$ & $\begin{array}{l}0.02 \\
(1.12)\end{array}$ & $\begin{array}{l}0.02 \\
(1.04)\end{array}$ & $\begin{array}{l}0.03 \\
(1.14)\end{array}$ \\
\hline$\overline{\text { SIZE }}$ & $\begin{array}{l}-0.02 \\
(-2.09)^{*}\end{array}$ & $\begin{array}{l}-0.01 \\
(-1.84)^{* *}\end{array}$ & $\begin{array}{l}-0.01 \\
(-1.71)^{* *}\end{array}$ & $\begin{array}{l}-0.01 \\
(-1.75)^{* *}\end{array}$ & $\begin{array}{l}-0.03 \\
(-3.85)^{*}\end{array}$ & $\begin{array}{l}-0.03 \\
(-4.91)^{*}\end{array}$ & $\begin{array}{l}-0.03 \\
(-4.35)^{*}\end{array}$ & $\begin{array}{l}-0.04 \\
(-5.03)^{*}\end{array}$ \\
\hline$\overline{\mathrm{R}^{2}}$ & 0.328 & 0.312 & 0.309 & 0.309 & 0.694 & 0.711 & 0.675 & 0.684 \\
\hline ADJ. $\mathrm{R}^{2}$ & 0.322 & 0.306 & 0.302 & 0.302 & 0.666 & 0.684 & 0.645 & 0.655 \\
\hline
\end{tabular}


Continued Table $3 a$

\begin{tabular}{lllllllll}
\hline $\begin{array}{l}\text { Regressions/ } \\
\text { Variable }\end{array}$ & \multicolumn{3}{c}{ Pooled Regression } & \multicolumn{4}{c}{$\begin{array}{l}\text { Fixed Effect Regression } \\
\text { (with cross-section weights) }\end{array}$} \\
\cline { 2 - 10 } & 1 & 2 & 3 & 4 & 1 & 2 & 3 & 4 \\
\hline F-STAT & 50.23 & 46.73 & 46.06 & 45.97 & 24.40 & 26.45 & 22.38 & 23.27 \\
& $(0.00)$ & $(0.00)$ & $(0.00)$ & $(0.00)$ & $(0.00)$ & $(0.00)$ & $(0.00)$ & $(0.00)$ \\
\hline Fixed effects & - & - & - & - & $14.79^{*}$ & $16.97^{*}$ & $17.91^{*}$ & $18.47^{*}$ \\
test (F-test) & & & & & $(0.00)$ & $(0.00)$ & $(0.00)$ & $(0.00)$ \\
\hline
\end{tabular}

*(**) Significant at 5\% (10\%) level

Note: Null hypothesis for the fixed effects test: Fixed effects are not significant.

Table 3b. Regression of net operating profit on working capital variables

\begin{tabular}{|c|c|c|c|c|c|c|c|c|}
\hline \multirow{2}{*}{$\begin{array}{l}\text { Regressions/ } \\
\text { Variable }\end{array}$} & \multicolumn{4}{|c|}{ Pooled Regression } & \multicolumn{4}{|c|}{$\begin{array}{l}\text { Fixed Effect Regression } \\
\text { (with cross-section weights) }\end{array}$} \\
\hline & 1 & 2 & 3 & 4 & 1 & 2 & 3 & 4 \\
\hline$\overline{\mathrm{C}}$ & $\begin{array}{l}0.48 \\
(1.51) \\
\end{array}$ & $\begin{array}{l}0.50 \\
(1.54) \\
\end{array}$ & $\begin{array}{l}0.41 \\
(1.32) \\
\end{array}$ & $\begin{array}{l}0.57 \\
(1.78)^{* *} \\
\end{array}$ & $\begin{array}{l}1.40 \\
(11.43)^{*}\end{array}$ & $\begin{array}{l}1.37 \\
(9.84)^{*}\end{array}$ & $\begin{array}{l}1.33 \\
(8.99) * \\
\end{array}$ & $\begin{array}{l}1.35 \\
(9.33)^{*}\end{array}$ \\
\hline$\overline{\mathrm{ACP}}$ & $\begin{array}{l}-0.002 \\
(-2.57)^{*}\end{array}$ & - & - & - & $\begin{array}{l}-0.001 \\
(-3.46)^{*}\end{array}$ & - & - & - \\
\hline$\overline{\mathrm{APP}}$ & - & $\begin{array}{l}-0.001 \\
(-2.03)^{*}\end{array}$ & - & - & - & $\begin{array}{l}-0.0001 \\
(-0.71)\end{array}$ & - & - \\
\hline$\overline{\mathrm{CCC}}$ & - & - & $\begin{array}{l}-0.001 \\
(-3.31)^{*}\end{array}$ & - & - & - & $\begin{array}{l}0.0002 \\
(1.59)\end{array}$ & - \\
\hline ITID & - & - & - & $\begin{array}{l}-0.001 \\
(-3.17)^{*}\end{array}$ & - & - & - & $\begin{array}{l}0.0001 \\
(1.50)\end{array}$ \\
\hline$\overline{\mathrm{CR}}$ & $\begin{array}{l}0.05 \\
(1.16)\end{array}$ & $\begin{array}{l}0.03 \\
(0.73)\end{array}$ & $\begin{array}{l}0.09 \\
(2.02)^{* *}\end{array}$ & $\begin{array}{l}-0.06 \\
(1.23)\end{array}$ & $\begin{array}{l}-0.03 \\
(-2.21)^{*}\end{array}$ & $\begin{array}{l}-0.04 \\
(-2.52)^{*}\end{array}$ & $\begin{array}{l}-0.04 \\
(-2.64)^{*}\end{array}$ & $\begin{array}{l}-0.04 \\
(-2.40)^{*}\end{array}$ \\
\hline FATA & $\begin{array}{l}1.29 \\
(8.09)^{*}\end{array}$ & $\begin{array}{l}1.23 \\
(7.57)^{*}\end{array}$ & $\begin{array}{l}1.26 \\
(7.93)^{*}\end{array}$ & $\begin{array}{l}1.28 \\
(8.00)^{*}\end{array}$ & $\begin{array}{l}0.60 \\
(11.83)^{*}\end{array}$ & $\begin{array}{l}0.59 \\
(10.89)^{*}\end{array}$ & $\begin{array}{l}0.59 \\
(10.97)^{*}\end{array}$ & $\begin{array}{l}0.58 \\
(10.74)^{*}\end{array}$ \\
\hline$\overline{\text { GRT }}$ & $\begin{array}{l}0.003 \\
(4.12)^{*}\end{array}$ & $\begin{array}{l}0.003 \\
(4.37)^{*}\end{array}$ & $\begin{array}{l}0.003 \\
(3.93)^{*}\end{array}$ & $\begin{array}{l}0.003 \\
(4.08)^{*}\end{array}$ & $\begin{array}{l}0.001 \\
(7.59) \\
\end{array}$ & $\begin{array}{l}0.001 \\
(7.54)^{*}\end{array}$ & $\begin{array}{l}0.001 \\
(7.88)^{*}\end{array}$ & $\begin{array}{l}0.001 \\
(8.14)^{*} \\
\end{array}$ \\
\hline$\overline{\mathrm{LEV}}$ & $\begin{array}{l}-0.42 \\
(-5.10) *\end{array}$ & $\begin{array}{l}-0.40 \\
(-4.84)^{*}\end{array}$ & $\begin{array}{l}-0.44 \\
(-5.34)^{*}\end{array}$ & $\begin{array}{l}-0.45 \\
(-5.41)^{*}\end{array}$ & $\begin{array}{l}-0.35 \\
(-9.18)^{*}\end{array}$ & $\begin{array}{l}-0.35 \\
(-8.75)^{*}\end{array}$ & $\begin{array}{l}-0.35 \\
(-8.71)\end{array}$ & $\begin{array}{l}-0.35 \\
(-8.72)^{*}\end{array}$ \\
\hline$\overline{\text { SIZE }}$ & $\begin{array}{l}-0.05 \\
(-2.64)^{*}\end{array}$ & $\begin{array}{l}-0.05 \\
(-2.51)^{*}\end{array}$ & $\begin{array}{l}-0.05 \\
(-2.82) *\end{array}$ & $\begin{array}{l}-0.05 \\
(-2.74)^{*}\end{array}$ & $\begin{array}{l}-0.08 \\
(-10.45)^{*}\end{array}$ & $\begin{array}{l}-0.08 \\
(-8.88)^{*}\end{array}$ & $\begin{array}{l}-0.08 \\
(-8.37)^{*}\end{array}$ & $\begin{array}{l}-0.08 \\
(-9.04) *\end{array}$ \\
\hline $\mathrm{R}^{2}$ & 0.181 & 0.177 & 0.186 & 0.185 & 0.670 & 0.651 & 0.648 & 0.654 \\
\hline ADJ. $\mathrm{R}^{2}$ & 0.173 & 0.169 & 0.179 & 0.177 & 0.639 & 0.618 & 0.616 & 0.622 \\
\hline$\overline{\text { F-STAT }}$ & $\begin{array}{l}22.69 \\
(0.00)\end{array}$ & $\begin{array}{l}22.19 \\
(0.00)\end{array}$ & $\begin{array}{l}23.57 \\
(0.00)\end{array}$ & $\begin{array}{l}23.38 \\
(0.00)\end{array}$ & $\begin{array}{l}21.85 \\
(0.00)\end{array}$ & $\begin{array}{l}20.03 \\
(0.00)\end{array}$ & $\begin{array}{l}19.82 \\
(0.00)\end{array}$ & $\begin{array}{l}20.32 \\
(0.00)\end{array}$ \\
\hline $\begin{array}{l}\text { Fixed effects test } \\
\text { (F-test) }\end{array}$ & - & - & - & - & $\begin{array}{l}11.91 \\
(0.00)\end{array}$ & $\begin{array}{l}12.85 \\
(0.00) \\
\end{array}$ & $\begin{array}{l}13.23 \\
(0.00)\end{array}$ & $\begin{array}{l}13.60 \\
(0.00) \\
\end{array}$ \\
\hline
\end{tabular}

$*(* *)$ Significant at $5 \%(10 \%)$ level

Note: Null hypothesis for the fixed effects test: Fixed effects are not significant.

Starting with Table 3a, the pooled regression results show that profitability measured by GOI, is negatively and significantly related to ACP and APP, while that of ITID and 
the CCC are positive but insignificant. This therefore implies WCM practices have not been efficient. Similarly, CR, LEV, and size bear significant negative relationship with GOI. FATA and GRT are positively linked with GOI. However, only that of FATA is significant.

Table 3c. Regression of return on assets on working capital variables

\begin{tabular}{|c|c|c|c|c|c|c|c|c|}
\hline \multirow{2}{*}{$\begin{array}{l}\text { Regressions/ } \\
\text { Variable }\end{array}$} & \multicolumn{4}{|c|}{ Pooled Regression } & \multicolumn{4}{|c|}{$\begin{array}{l}\text { Fixed Effect Regression (with cross- } \\
\text { section weights) }\end{array}$} \\
\hline & 1 & 2 & 3 & 4 & 1 & 2 & 3 & 4 \\
\hline$\overline{\mathrm{C}}$ & $\begin{array}{l}0.02 \\
(0.42)\end{array}$ & $\begin{array}{l}0.01 \\
(0.15)\end{array}$ & $\begin{array}{l}-0.03 \\
(-0.53)\end{array}$ & $\begin{array}{l}-0.02 \\
(-0.28)\end{array}$ & $\begin{array}{l}0.33 \\
(8.41)^{*}\end{array}$ & $\begin{array}{l}0.32 \\
(7.65)^{*}\end{array}$ & $\begin{array}{l}0.34 \\
(8.17)^{*}\end{array}$ & $\begin{array}{l}0.34 \\
(7.93)^{*}\end{array}$ \\
\hline$\overline{\mathrm{ACP}}$ & $\begin{array}{l}-0.001 \\
(-6.14)^{*}\end{array}$ & - & - & - & $\begin{array}{l}-0.0002 \\
(-4.13)^{*}\end{array}$ & - & - & - \\
\hline APP & - & $\begin{array}{l}-0.0001 \\
(-3.30)^{*}\end{array}$ & - & - & - & $\begin{array}{l}-0.00001 \\
(-3.66)^{*}\end{array}$ & - & - \\
\hline$\overline{\mathrm{CCC}}$ & - & - & $\begin{array}{l}-0.0002 \\
(-2.66)^{*}\end{array}$ & - & - & - & $\begin{array}{l}0.00003 \\
(1.01)\end{array}$ & - \\
\hline ITID & - & - & - & $\begin{array}{l}-0.0001 \\
(-1.86)^{* *}\end{array}$ & - & - & - & $\begin{array}{l}0.00001 \\
(0.45)\end{array}$ \\
\hline$\overline{\mathrm{CR}}$ & $\begin{array}{l}-0.003 \\
(-0.40) \\
\end{array}$ & $\begin{array}{l}-0.01 \\
(-1.19)\end{array}$ & $\begin{array}{l}0.001 \\
(0.13)\end{array}$ & $\begin{array}{l}-0.01 \\
(-0.63)\end{array}$ & $\begin{array}{l}-0.014 \\
(-4.01)^{*}\end{array}$ & $\begin{array}{l}-0.014 \\
(-3.79)^{*} \\
\end{array}$ & $\begin{array}{l}-0.014 \\
(-3.68)^{*}\end{array}$ & $\begin{array}{l}-0.013 \\
(-3.68)^{*}\end{array}$ \\
\hline$\overline{\text { FATA }}$ & $\begin{array}{l}0.20 \\
(7.46)^{*}\end{array}$ & $\begin{array}{l}0.18 \\
(6.48)^{*}\end{array}$ & $\begin{array}{l}0.19 \\
(6.98)^{*}\end{array}$ & $\begin{array}{l}0.19 \\
(7.03)^{*}\end{array}$ & $\begin{array}{l}0.13 \\
(8.33)^{*}\end{array}$ & $\begin{array}{l}0.13 \\
(8.04)^{*}\end{array}$ & $\begin{array}{l}0.12 \\
(7.65)^{*}\end{array}$ & $\begin{array}{l}0.12 \\
(7.65)^{*}\end{array}$ \\
\hline GRT & $\begin{array}{l}0.0004 \\
(3.79)^{*}\end{array}$ & $\begin{array}{l}0.001 \\
(4.30)^{*}\end{array}$ & $\begin{array}{l}0.0004 \\
(3.92)^{*}\end{array}$ & $\begin{array}{l}0.001 \\
(4.11)^{*}\end{array}$ & $\begin{array}{l}0.0003 \\
(6.87)^{*}\end{array}$ & $\begin{array}{l}0.0003 \\
(6.50)\end{array}$ & $\begin{array}{l}0.0003 \\
(7.15)\end{array}$ & $\begin{array}{l}0.0003 \\
(7.03)^{*}\end{array}$ \\
\hline$\overline{\mathrm{LEV}}$ & $\begin{array}{l}-0.10 \\
(-7.51)^{*}\end{array}$ & $\begin{array}{l}-0.10 \\
(-6.91)^{*}\end{array}$ & $\begin{array}{l}-0.11 \\
(-7.41)^{*}\end{array}$ & $\begin{array}{l}-0.11 \\
(-7.36)^{*}\end{array}$ & $\begin{array}{l}-0.08 \\
(-6.93) \\
\end{array}$ & $\begin{array}{l}-0.08 \\
(-6.94)^{*} \\
\end{array}$ & $\begin{array}{l}-0.08 \\
(-6.97)^{*} \\
\end{array}$ & $\begin{array}{l}-0.08 \\
(-6.99) \\
\end{array}$ \\
\hline SIZE & $\begin{array}{l}0.001 \\
(0.39)\end{array}$ & $\begin{array}{l}0.002 \\
(0.57)\end{array}$ & $\begin{array}{l}0.002 \\
(0.49) \\
\end{array}$ & $\begin{array}{l}0.002 \\
(0.61)\end{array}$ & $\begin{array}{l}-0.02 \\
(-7.79)^{*}\end{array}$ & $\begin{array}{l}-0.02 \\
(-7.01)^{*}\end{array}$ & $\begin{array}{l}-0.02 \\
(-7.97) *\end{array}$ & $\begin{array}{l}-0.02 \\
(-7.92) * \\
\end{array}$ \\
\hline R2 & 0.196 & 0.162 & 0.157 & 0.152 & 0.675 & 0.660 & 0.663 & 0.664 \\
\hline ADJ. R2 & 0.188 & 0.154 & 0.148 & 0.143 & 0.645 & 0.628 & 0.631 & 0.633 \\
\hline F-STAT & $\begin{array}{l}25.09 \\
(0.00)\end{array}$ & $\begin{array}{l}19.84 \\
(0.00)\end{array}$ & $\begin{array}{l}19.10 \\
(0.00)\end{array}$ & $\begin{array}{l}18.39 \\
(0.00)\end{array}$ & $\begin{array}{l}22.38 \\
(0.00)\end{array}$ & $\begin{array}{l}20.87 \\
(0.00)\end{array}$ & $\begin{array}{l}21.12 \\
(0.00)\end{array}$ & $\begin{array}{l}21.29 \\
(0.00)\end{array}$ \\
\hline $\begin{array}{l}\text { Fixed effects } \\
\text { test (F-test) }\end{array}$ & - & - & - & - & $\begin{array}{l}15.16^{*} \\
(0.00)\end{array}$ & $\begin{array}{l}15.78 \\
(0.00)\end{array}$ & $\begin{array}{l}17.09 \\
(0.00)\end{array}$ & $\begin{array}{l}17.11 \\
(0.00)\end{array}$ \\
\hline
\end{tabular}

$*(* *)$ Significant at $5 \%(10 \%)$ level

Note: Null hypothesis for the fixed effects test: Fixed effects are not significant.

The results from the fixed effects regression present a stronger evidence of the inefficiency of the WCM practices given that all the measures of WCM are negatively and significantly signed with GOI. The positive and negative impacts of FATA and SIZE, respectively like in the pooled regression are also significant. CR retains its negative impact but with significance only on APP. Similarly, LEV retains its positive impact but lost its significance.

In Table 3b, the results reflect a somewhat transpose of those in table $3 \mathrm{a}$. This is because the pooled regression results in this instance provide a stronger evidence of the inefficiency in the WCM practices. All the measures of WCM show significant negative 
relationship to NOI. In contrast, the results from the fixed effects regression present weak evidences of inefficient WCM except for ACP with a significant impact. This result suggests that ACP is longer than the minimum required and as such had negative impact. FATA and GRT bear significant positive impact while LEV and SIZE exerted significant negative influences in both the pooled and fixed effects regressions. The impact of CR showed mixed results. It is positive in the pooled regression but negative in the fixed effects regression. However, while its impact in the pooled estimation was largely insignificant, it was significant in the fixed effect regression. This implies a trade-off between CR and profitability.

The results obtained with the use of ROA as the measure of profitability (Table 3c) parallel that obtained from using NOI. Results from both the pooled and fixed effect regressions showed that the WCM is inefficient and has therefore caused reduction in profitability. Both FATA and GRT had significant positive impacts. In contrast, CR, LEV and SIZE had significant negative impacts.

In summary, the WCM of the firms have been inefficient and thereby negatively affected their profitability. This result/conclusion is similar to the findings of Shin and Soenen (1988), Deloof (2003), Padachi (2006), Raheman and Nasr (2007) and Karaduman et al. (2010).

\section{Summary and conclusion}

This paper investigated the relationship between efficiency of WCM and profitability of a sample of 48 manufacturing firms in Nigeria during the period 1993 to 2005. The motivation is underpinned by the inadequacy and weaknesses in a previous study by Falope and Ajilore (2009). Thus, the study is aimed at contributing to expanding and enriching the literature particularly on Nigeria and at large.

The investigation examined the responses of the firms' profitability to WCM and a number of augmenting factors namely CR, LEV, GRT, FATA and size. Profitability was alternatively measured by GOI, NOI and ROA. Likewise, WCM was measured by the ACP, APP, ITID and comprehensively by the CCC.

The results indicated the firms' have been inefficient with their WCM and caused reductions in their profitability. This is similar to the findings of Shin and Soenen (1988), Deloof (2003), Padachi (2006), Raheman and Nasr (2007) and Karaduman et al. (2010). In addition, CR, LEV, GRT, FATA and size also have significant effect on the firms' profitability just as reported by Samiloglu and Demigunes (2008).

On the strength of the results, the paper concluded that improving the efficiency of WCM is essential for the firms. The paper, therefore, recommended that manufacturing firms in Nigeria should shorten the ACP, APP and ITID, and reduce CCC towards enhancing their profitability. In addition, financial managers generally must accord importance to maintaining optimal and efficient WCM to guarantee profitability. For the investors with eye on high returns on their investment, proper scrutiny of WCM policies and management practices of firms should be done prior to making investments. Since 
the core of financial management consultancy is to provide informed opinion and guidance to clients, it is imperative that financial management consultants utilize the findings of empirical research like this paper in their practices.

However, some limitations of the study are recognized. First, is the small sample size of 48 firms. Second, the period covered (1993-2005) is somewhat dated. The third and the most significant is the lumping of all manufacturing firms together. There are ten sub sector classifications of the manufacturing sector in Nigeria. A sub-sector study would provide more insightful results. It is, therefore, suggested that further research focusing on sub sector analysis be conducted.

\section{References}

Ali, S.; Khan, M. R. 2011. Searching for internal and external factors that determine working capital management for manufacturing firms in Pakistan, African Journal of Business Management 5(7): 2942-2949

Appuhami, B. A. R. 2008. The impact of firms' capital expenditure on WCM: an empirical study across industries in Thailand, International Management Review 4(1): 8-21.

Bhattacharya, H. 2009, WCM: Strategies and Techniques, 2nd edition. PHI Learning Private Limited, New Delhi.

Biggs, T.; Mayank, R; Pradeep, S. 1996. Enforcement of contracts in an African market: working capital financing in Kenyan manufacturing: RPED discussion paper. African Technical Department. World Bank. Washington, D.C.

Charitou, M. S.; Elfani, M.; Lois, P. 2010. The effect of WCM on firm's profitability: empirical evidence from an emerging market, Journal of Business and Economics Research 8(12): 63-68.

Chiou, J.-R.; Cheng, L. 2006. The determinants of WCM, The Journal of American Academy of Business 10(1): 149-155.

Dănulețiu, A. E. 2010. WCM and profitability: a case of Alba county companies, Annales Universitatis Apulensis Series Oeconomica 12(1): 364-374.

Deloof, M.; Jegers, M. 1996. Trade credit, product quality, and intragroup trade: some European evidence, Financial Management 25: 33-43. http://dx.doi.org/10.2307/3665806

Deloof, M. 2003. Does WCM affects profitability of Belgian firms?, Journal of Business Finance and Accounting 30(3-4): 573-587. http://dx.doi.org/10.1111/1468-5957.00008

Eljelly, A. 2004. Liquidity-profitability tradeoff: an empirical investigation in an emerging market, International Journal of Commerce and Management 14(2): 48-61. http://dx.doi. org/10.1108/10569210480000179

Falope, O. I.; Ajilore, O. T. 2009. WCM and corporate profitability: evidence from panel data analysis of selected quoted companies in Nigeria, Research Journal of Business Management 3(3): 73-84. http://dx.doi.org/10.3923/rjbm.2009.73.84

Garcia-Teruel, P. J.; Martinez-Solano, P. 2007. Effects of WCM on SME profitability, International Journal of Managerial Finance 3(2): 164-177.

Gilbrat, R. 1931. Les Inequalities Economiques. Paris: Librairie du Recueil Sirey.

Gill, A.; Biger, N.; Mathur, N. 2010. The relationship between WCM and profitability: evidence from the United States, Business and Economics Journal 2010(10): 1-9.

Gitman, L. J. 1974. Corporate liquidity requirements: a simplified approach, The Financial Review 9(1): 79-88. http://dx.doi.org/10.1111/j.1540-6288.1974.tb01453.x

Gitman, L. J.; Sachdeva, K. S. 1984. A framework for estimating and analyzing the required working capital investment, Review of Business and Economic Research 17(3): 36-44.

Guthman, H. G.; Dougall, H. E. 1948. Corporate Financial Policy, 2nd edition. New York: PrenticeHall, Inc. 
Hawawini, G.; Viallet, C.; Vora, A. 1986. Industry influence on corporate working capital decisions, Sloan Management Review 27(4): 15-24.

Karaduman, H. A; Akbas, H. E.; Ozsozgun, A.; Durer, S. 2010. Effects of WCM on profitability: the case for selected companies in the Istanbul Stock Exchange (2005-2008), International Journal of Economics and Finance Studies 2(2): 47-54.

KPMG. 2005. WCM Survey: How do European Companies Manage their Working Capital? KPMG LLP.

Lazaridis, I.; Tryfonidis, D. 2006. Relationship between WCM and profitability of companies listed in the Athens Stock Exchange, Journal of Financial Management and Analysis 19(1): 26-35.

Long, M. S.; Malitz I. B.; Ravid, S. A. 1993. Trade credit, quality guarantees, and product marketability, Financial Management 22(4): 117-127. http://dx.doi.org/10.2307/3665582

Lukkari, E. 2011. WCM: a Bibliometric Study [online], [cited 14 August 2011]. Master's Thesis. Lappeenranta University of Technology, Industrial Management. Lappeenranta, Finland. Available from Internet: http://www.doria.fi/bitstream/handle/10024/67494/nbnfi-fe201103021294.pdf

Mathuva, D. 2009. The influence of WCM components on corporate profitability: a survey on Kenyan listed firms, Research Journal of Business Management 3(1): 1-11.

Michalski, G. 2007. Portfolio management approach in trade credit decision making, Romania Journal of Economic Forecast 3(1): 42-53.

Nazir, M. S, Afza, T. 2008. On the factor determining working capital requirements. Proc. ASBBS 15(1): 293-301.

Nazir, M. S, Afza, T. 2009. Working capital requirements and the determining factors in Pakistan, ICFAI Journal of Applied Finance 15 (4): 28-38.

Padachi, K. 2006. Trends in WCM and its impact on firms' performance: an analysis of Mauritian small manufacturing firms, International Review of Business Research Papers 2(2): 45-58.

Park, C.; Gladson, J. W. 1963. Working Capital. Macmillan, New York.

Planware. 2010. Business Planning Papers: Managing Working Capital [online], [cited 15 December 2010]. Available from Inernet: http://www.planware.org/workingcapital.htm

Raheman, A.; Nasr, M. 2007. WCM and profitability - case of Pakistani firms, International Review of Business Research Papers 3(1): 279-300.

Samiloglu, F.; Demigunes, K. 2008. The effect of WCM on firm profitability: evidence from Turkey, The International Journal of Applied Economics and Finance 2(1): 44-50. http://dx.doi.org/10.3923/ ijaef.2008.44.50

Seyaduzznmen, Md. 2006. WCM: a study on British American Tobacco Bangladesh Company Ltd, Journal of Nepalese Business Studies 3(1): 78-84.

Sharma, A. K.; Kumar, S. 2011. Effect of WCM on firm profitability empirical evidence from India, Global Business Review 12(2): 159-173. http://dx.doi.org/10.1177/097215091001200110

Shin, H. H.; Soenen, L. 1998. Efficiency of WCM and corporate profitability, Financial Practice and Education 8(2): 37-45.

Smith, K. V. 1973. State of the art of working capital management, Financial Management (Autumn): 50-55. http://dx.doi.org/10.2307/3664987

Van Horne, J. C.; Wachowicz, J. M. 2000. Fundamentals of Financial Management. 11th edition. Prentice Hall, Inc.

Van Horne, J. C.; Wachowicz, J. M. 2004. Fundamentals of Financial Management. 12th edition. New York: Prentice Hall Publishers

Omo AREGBEYEN holds a Ph.D. in Economics from the University of Ibadan, Ibadan, Nigeria. He has taught and conducted researches in a number of leading universities and institutions in the country. His teachings and research activities have focused more on Development/Public Sector Economics and Industrial Economics. Many of the research outputs of Dr Aregbeyen have appeared in learned journals both locally and internationally. He has also served as a consultant/resource person in a number of commissioned studies/projects nationally and internationally. Presently, he is with the Department of Economics, University of Ibadan, Ibadan and the Director of postgraduate academic programmes. 